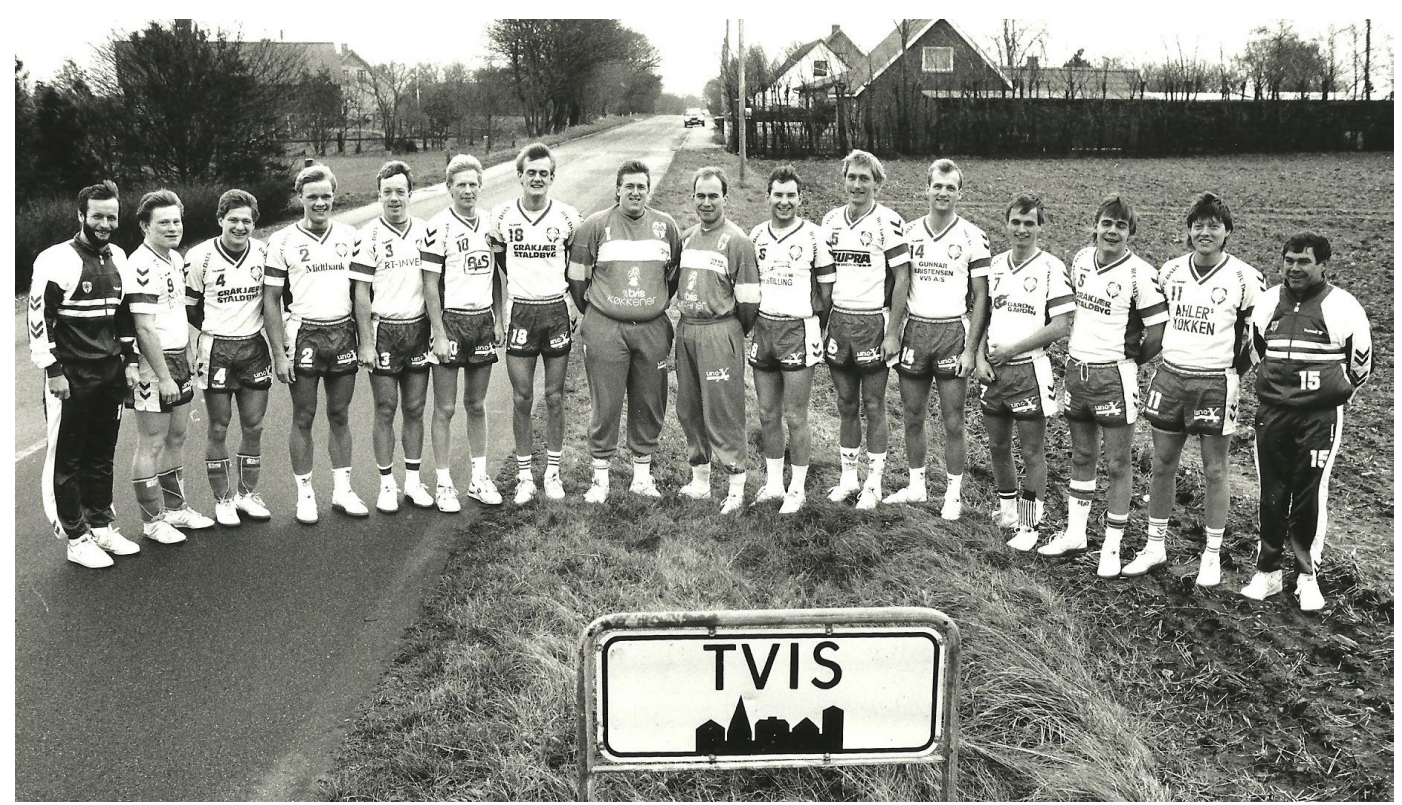

Tvis KFUM's nyoprykkede 2. divisionshold i sæsonen 1990/91. Træner Kurt Nielsen er helt til venstre og anfører John Mikkelsen nr. 3 fra højre. Foto: Dagbladet Holstebro.

\title{
Fra marken til arenaen
}

\section{Historien om dansk klubhåndbold med Tvis KFUM som eksempel}

\author{
HANS HENRIK HJERMITSLEV
}

Formålet med denne artikel er at benytte Tvis KFUM som case til at beskrive dele af den generelle udvikling inden for klubhåndbolden i Danmark. Historien om Tvis KFUM er nemlig på mange måder typisk for de ændringer, der har fundet sted i mange succesrige landsby- og KFUM-klubber gennem de sidste 40 år. Klubben er således gået fra at være en lokalt og ideologisk forankret kristen forening til at blive et professionelt aktieselskab med regionalt fokus. Den har samtidig været igennem følelsesladede fusionsprocesser og økonomiske vanskeligheder i denne transformation fra forening til forretning. Som analytisk ramme for Tvis KFUM’s og håndboldens udvikling generelt benyttes et topografisk greb ved at fokusere på stedets betydning for håndbolden i tråd med den såkaldte 'vending mod rummet' inden for humanistisk og sociologisk forskning. 


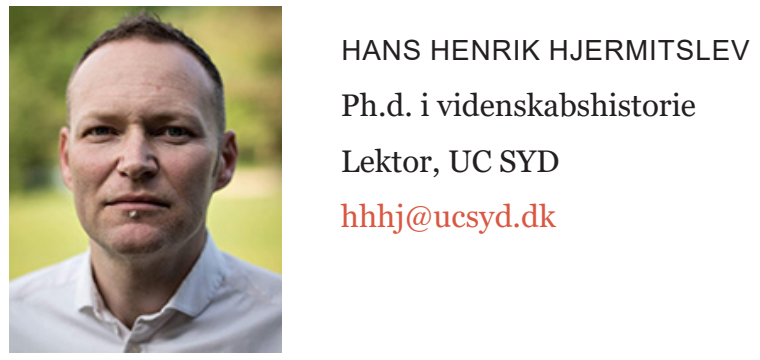

Håndbold er blandt de absolut mest populære idrætsgrene i Danmark målt på antallet af udøvere og tilskuere. På landsholds- og klubniveau har der desuden siden 1990'erne været en vedvarende sportslig succes med en lind strøm af internationale topplaceringer på både dame- og herresiden. Da det samtidig er én af de få idrætsgrene, der er opfundet i Danmark, kan det med god ret hævdes, at håndbold er blandt landets mest prominente idrætsgrene (Storm 2008).

Inden for idrætsforskningen har dansk klubhåndbold da også tiltrukket sig en vis interesse. En række sociologiske og økonomiske studier har analyseret professionaliseringen og kommercialiseringen af elitehåndbolden fra 1990'erne og frem, hvor udviklingen fra forening til forretning har resulteret i en øget pengestrøm og interesse, men også i en kronisk dårlig økonomi i eliteklubberne med mange konkurser til følge (Storm \& Almlund 2006; Storm 2008; Idan 2018).

Der eksisterer også en række historiske undersøgelser af klubhåndbolden i Danmark. Lokalhistoriske studier har dokumenteret håndboldens opkomst som indendørssport i byerne i 1920'erne og dens folkelige gennembrud som udendørsspil på landet i tiden omkring Anden Verdenskrig, hvor antallet af aktive håndboldspillere steg fra 29.110 i 1938 til 59.000 i 1943. Dette gennembrud var tæt knyttet til sportens indtog i den organiserede foreningsidræt under de grundtvigske organisationer DDG og DDSG\&I og det indremissionske KFUM's Idrætsforbund. I disse ideologisk prægede organisationer blev håndbold opfattet som et mere moralsk acceptabelt supplement til den traditionelle gymnastik end fodbold, der blev set ned på som en brutal arbejdersport (Korsgaard 1997; Christensen 1999). Fra 1970'erne skete der en afideologisering af håndbolden i takt med, at de dygtige spillere forlod barndomsklubberne til fordel for mere og mere resultatorienterede eliteklubber, der nu tilbød diæter, udstyr og systematisk træning frem for opbyggelige foredrag, fællessang og andagter. Niels Kayser Nielsen har bekrevet denne begyndende professionalisering af håndbolden som en forfaldshistorie om transformationen af spillerne fra aktive medlemmer af en lokalt forankret idrætsforening til lønnede medarbejdere i en sportsvirksomhed inden for underholdningsindustrien og ople- 
velsesøkonomien (Nielsen 2008; 2010).

Inden for den historiske forskning savnes der imidlertid undersøgelser af udviklingen fra 1970 og frem. Formålet med denne artikel er at råde bod på dette ved at benytte Tvis KFUM som case til at beskrive nogle aspekter af den generelle udvikling inden for klubhåndbolden i Danmark. Historien om Tvis KFUM er nemlig på mange måder typisk for de ændringer, der har fundet sted i mange succesrige klubber gennem de sidste 40 år. Klubben er således gået fra at være en lokalt og ideologisk forankret kristen forening til at blive et professionelt aktieselskab med regionalt fokus. Den har samtidig været igennem følelsesladede fusionsprocesser og økonomiske vanskeligheder i denne transformation fra forening til forretning (Storm 2008; Bak 2014; 2016).

Som analytisk ramme for Tvis KFUM's og håndboldens udvikling generelt benytter jeg et topografisk greb ved at fokusere på stedets betydning for håndbolden i tråd med den såkaldte 'vending mod rummet' inden for humanistisk og sociologisk forskning. Som Niels Kayser Nielsen har påvist, så spiller stedet en særlig rolle for håndboldens udvikling, da det var de konkrete fysiske rammer på sportspladser og i gymnastiksale, industribygninger, kaserner og idrætshaller, der var afgørende for både håndboldens tekniske og taktiske muligheder og udvikling og for tilskuernes oplevelser i 1960'erne. Med etableringen af hundredevis af idrætshaller i 1970'erne blev håndboldens steder mere ens. Hallerne mindede om hinanden og banens mål blev standardiserede, så hjemmebanerne mistede noget af deres lokale egenart. På trods af denne bevægelse mod homogenisering og delokalisering, beholdt håndboldens steder imidlertid stadig noget af deres topografiske særpræg. Både spillere og tilskuere identificerer sig nemlig med et sted, da de føler sig hjemme på deres hjemmebane. Det at støtte det lokale hold er en måde at styrke og bekræfte ens kulturelle tilhørsforhold til et bestemt sted på (Nielsen 2010). Den lokale identitet opbygges gennem fortællinger om det særlige ved dette spillested, og i nogle tilfælde udtrykkes kærligheden til stedet ved at give hjemmebanen kælenavne såsom Cigaræsken i Skanderborg, Skansen i Sønderborg og Stalden i Holstebro.

Transformationen af håndboldens spillesteder for Tvis KFUM afspejler den typiske udvikling af håndbolden på landet i Danmark. Håndbolden begyndte på en mark i 1942 og flyttede i 1968 til et stadion ved den nye centralskole. I 1978 blev Tvis Hallen indviet som ny indendørs hjemmebane, og i 1991 rykkede herrernes hjemmekampe i 2. division til Idrætscenter Vest i Holstebro, der fungerede som hjemmebane, indtil Gråkjær Arena blev indviet i 2011.

Artiklen er hovedsageligt baseret på lokalhistoriske beretninger om Tvis KFUM’s historie skrevet af Bent Bak samt kildemateriale fra arkiver og hjemmesider (Bak 2014; 2016). ${ }^{1}$

1 Denne artikel er skrevet til minde om idrætsforskeren Dan Nørgaard Laursen (1973-2014), der søsatte projektet 'Fra marken til arenaen: Tvis KFUM 1942-2017' sammen med mig i 2014. 


\section{MARKEN}

Tvis er en landsby $7 \mathrm{~km}$ sydøst for købstaden Holstebro. Den er placeret i det vidtstrakte Tvis Sogn, der fungerede som sognekommune indtil kommunesammenlægningen med Holstebro i 1970. Med etableringen af jernbanen mellem Holstebro og Herning i 1904 blev landsbyen til en stationsby med kirke, købmand og mejeri. I begyndelsen af 1900-tallet blomstrede der i Tvis et frodigt kirke- og foreningsliv med rod i henholdsvis Indre Mission og grundtvigianisme. Foreningslivet var som i andre landsogne hovedsageligt båret af sognets gårdmænd og husmænd og deres familier, karle og piger. I 1904 blev der etableret et missionshus og i 1909 et forsamlingshus for de grundtvigsk sindede. I forsamlingshuset var der, ud over møder, foredrag, dilettant og fester, gymnastik om vinteren. I 1932 blev Tvis Idrætsforening stiftet med indendørs gymnastik om vinteren og udendørs fodbold for karle og udendørs håndbold for piger om sommeren (Bak 2018b; Fibiger 2018; Halgaard \& Bak 2018; Carlsen \& Henriksen 2018).

Sognets indremissionske familier var imidlertid forbeholdne over for at lade deres børn og tjenestefolk deltage i idrætsforeningens verdslige arrangementer. Derfor valgte man at oprette en håndboldklub under navnet Østergaards Boldklub i 1942. Den havde hjemme hos gårdejer Otto Østergaard Hansen og hans søn Ejner Østerholm Hansen, der stillede en velegnet græsmark i et lukket egekrat 2 km sydøst for Tvis by til rådighed. På denne måde kunne drenge og piger fra missionske hjem dyrke et kristent funderet idrætsfællesskab på sikker afstand af boldbanerne i byen. Da klubbens vedtægter blev nedskrevet i 1945, ændrede Østergaards Boldklub navn til Tvis K.F.U.M. og K.'s Haandboldforening og blev dermed en underafdeling af de 'civile' indremissionske ungdomsforeninger KFUM og KFUK, der var blevet oprettet i sognet i henholdsvis 1923 og 1932. I vedtægterne trådte det kristne livssyn - og betænkelighederne ved boldspil - tydeligt frem. Formålet med foreningen var således: "1. At dyrke Haandbold under kristeligt Ledelse. 2. At udnytte de unges Fritid paa en god og sund Maade." Efterfølgende blev det konkretiseret hvilket sindelag og hvilken opførsel, der krævedes af medlemmerne:

"1. Bestyrelsen af denne Forening skal være Medlemmer af K.F.U.M. eller K.F.U.K. i Sognet.

2. Lederen af Spillet skal altid være en afgjort Kristen.

3. Enhver Mand som Kvinde kan være Medlem af Foreningen.

4. Tonen skal altid være sund og ren på Banen.

5. Der skal altid sluttes med Andagt.

6. Naar der er holdt Andagt er det enhver af Medlemmernes Pligt at forlade Pladsen."

(Bak 2014, s. 9) 
Da samtidig to af bestyrelsens fem medlemmer var indsat af Tvis K.F.U.M. og K.'s bestyrelse, havde det missionske bagland ganske stor kontrol med foreningen og dens idrætsaktiviteter. Mens man i begyndelsen ud over træning mest spillede kampe mod naboklubber til sportsfester og deltog i Hjerm Herreds håndboldturnering, så blev foreningen i 1949 medlem af KFUM's Idrætsforbund (stiftet i 1918), ændrede navn til Tvis KFUM og K's Idræt og deltog nu i den regionale KFUMkreds' sommerturneringer, hvor man efterhånden kunne stille med hold for både herrer og damer i såvel junior- som seniorrækkerne. Sportsligt klarede foreningen sig relativt godt med optrædener i både mester- og A-rækkerne. I 1950'erne blomstrede KFUM-håndbolden i Vestjylland, hvor Indre Mission stod stærkt. Samtidig var der stadig mange unge mennesker, der tjente på landet. Det betød, at der var andre KFUM-klubber - f.eks. Vinding og Aulum - tæt på, som man kunne dyste med i en fælles kristelig atmosfære. Både trænings- og turneringsaftener afsluttedes med fælles andagt. Blandt højdepunkterne i sæsonen var sportsfesterne. Tvis KFUM og K’s Idræt arrangerede selv en sportsfest med turnering søndag eftermiddag efter kirketiden og aftenfest og deltog også i naboklubbernes sportsfester, der som turneringen foregik i en kristelig atmosfære med sang, taler og sanglege, men uden alkohol og dans (Bak 2014).

Håndbolden var på denne måde en del af en samlet indremissionsk landbokultur, der indbefattede opbyggelige IM- og KFUM og K-møder, bibelkredse, søndagsskole og juletræsfest i missionshuset. Parallelt hermed arrangerede den grundtvigske idræts- og ungdomsforening foredrag, oplæsning, dilettant, folkedans, bal og juletræsfest i forsamlingshuset. Så selv om børnene gik i skole og kirke sammen, de unge ofte arbejdede sammen, og de missionske og grundtvigske landmænd boede side om side, så levede de adskilte liv i fritiden. Selv om der generelt var et godt samarbejde i sogneråd, skole, kirke og mejeri mellem de to grupper, så kunne der da også opstå visse gnidninger. De børn og unge fra missionske hjem, der spillede håndbold i Østergaard Krat, blev hånligt kaldt 'kratunger' af medlemmer af idrætsforeningen, og blandt missionsfolkene var mange forargede over den 'syndige' livsførelse blandt de grundtvigske sognebørn (Bak 2014; Fibiger 2018).

Hjemmebanen i Østergaard Krat var på flere måder et ideelt sted til håndbold. Marken var omkranset af en tæt egetræsbevoksning, der beskyttede mod vestenvinden og samtidig gav mulighed for diskret omklædning. Bevoksningen betød også, at spillere og tilskuere kunne søge mod sol eller skygge alt efter vejret. Krattet var før 1942 blevet benyttet til skyttefester og fodbold, men nu kom håndbold i centrum. Der blev etableret én og senere to baner på tværs af lysningen i krattet i den ene ende, mens kreaturer græssede i den anden. Dette var meget fine forhold sammenlignet med andre landsbyklubber, der ofte måtte låne forblæste, ujævne og stenede marker af landmænd for et par år ad gangen (Bak 2014).

Spillerne beretter da også om en intim atmosfære og et særligt fællesskab i 


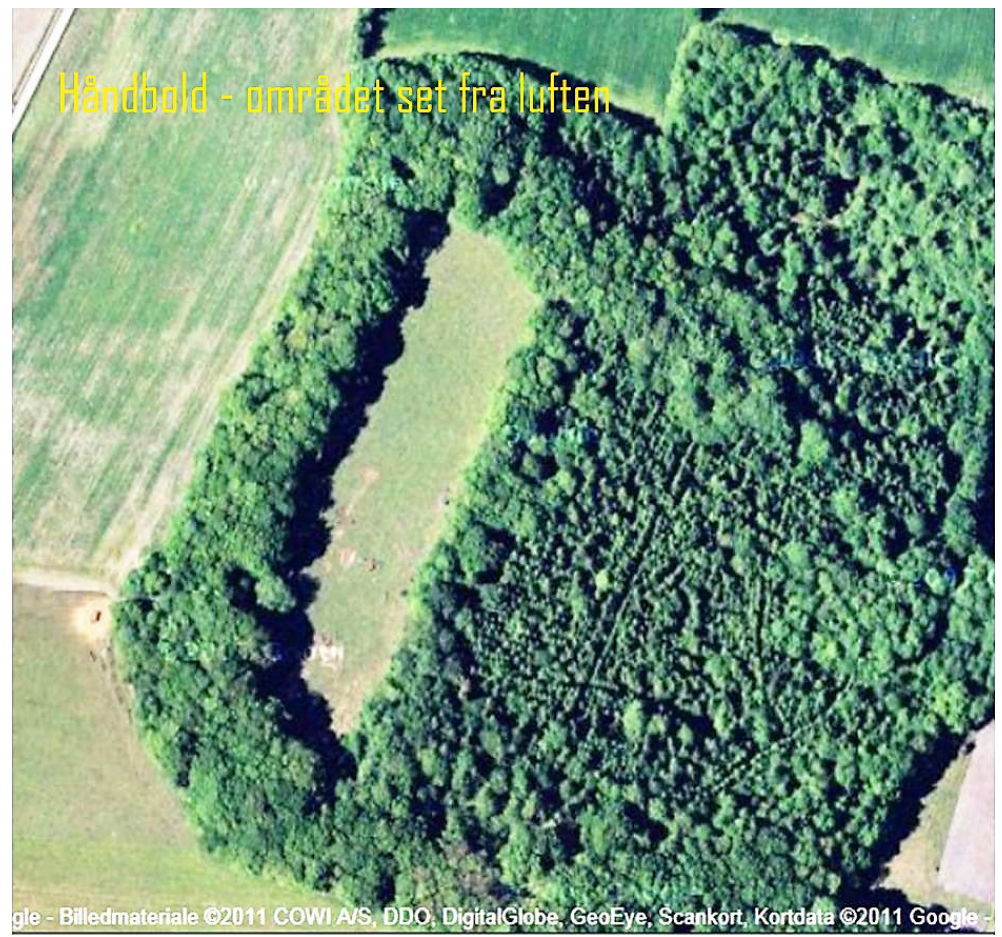

Figur 1: Østergård Krat. Tvis KFUM og K's Idræts hjemmebane 1942-1968. Foto: Bent Bak/Google Maps.

Østergård Krat i månederne fra maj til september, hvor der blev spillet sommerhåndbold:

"Efter træningen eller efter en turneringsaften samledes alle til andagt/appel. Man blev på stedet, indtil der var sluttet af. Det gjaldt også dem, som havde spillet kamp en time før. Et bevis på, at man ikke bare var holdspiller men klubspiller. Alle for klubben og klubben for alle. Det var ilde set, hvis man smuttede før den fælles afslutning, som også blev brugt til informationer.

Appel bestod af en aftensang fra De Unges Sangbog. Derefter var der et lille kristent indslag af en fra KFUM og K. Det kunne være en læsning fra bibelen, fra en andagtsbog, eller fra et skrift man var faldet over, og som man syntes talte til de unge. Andagtsholderen kunne så føje sine egne ord til oplæsningen. Der blev sluttet med en bøn. Derefter sang man igen 1 eller 2 sange/salmer. Ifølge medlemmerne fra den gang blev der sunget godt igennem, og kom man forbi på Brejnholtvej, som ligger 400 meter fra krattet, $i$ mørkningstimen, kunne man høre sangen $i$ den klare aftenluft. Vinden var i løbet af aftenen faldet helt til ro, og hvilken sang i den fredfyldte atmosfære efter kampen om flest mål kunne være mere velvalgt end: 'Fred hviler over land og by'.

Først på aftenen hang lærken over den grønne mark med sine triller. Nu un- 
der aftensangen var det sangdroslen og solsorten, man hørte imellem versene og efter sidste vers fra egetræernes krone.

Aftenen kunne være kølig, og havde man svedt, dampede kroppene og trak varmen ud med sveden. Her var det vigtig at få noget overtøj på. Man kom hurtigt til at fryse, hvis det var en kold forårsaften.

Hjemturen på cyklen kunne på de lune, stille sommeraftener være en fantastisk oplevelse. Det var ved at være mørkt, og der var mange at følges med $i$ starten, men efterhånden slog de fra, efterhånden som de kom til deres vej og gård. Var man ikke færdig med at snakke stoppede de unge op, og man kunne der $i$ et vejkryds stå og snakke om spillet, om modstanderne, om arbejde, ja også om nogle af de store spørgsmål i livet. Når månen steg op og stjernerne kom på himlen blev sindet mere alvorsstemt. Det kunne også være den unge fyr og pige der sådan diskret kunne stå og snakke i tusmørket, mens agerhønsenes kaldestemme til natten hørtes på marken.” (Bak, 2014, s. 17)

\section{STADIONET}

De trygge og idylliske omgivelser i Østergård Krat forblev klubbens hjemmebane i 26 år. Placeringen var ideel i både sportslig og ideologisk henseende, da krattet var perfekt til håndbold og samtidig lå på tilpas stor afstand af den grundtvigske Tvis Idræts- og Ungdomsforening, der havde deres idrætsanlæg inde ved landsbyens sognegård et par kilometer vest for krattet. 1960'ernes eksplosive udbygning af velfærdssamfundet fik imidlertid vidtrækkende konsekvenser for kultur- og idrætslivet i Danmark. Det gjaldt også i Tvis Sogn. I 1964 blev tre af sognets fire små landsbyskoler lukket til fordel for en stor centralskole ved kirken. Den nye skole havde de nødvendige faciliteter til at leve op til Skoleloven fra 1958, heriblandt en gymnastiksal, der blev et nyt centrum for vinteridrætten i Tvis. Her udvidede Tvis KFUM \& K's Idræt aktiviteterne med volleyball og badminton i 1970'erne. Samme år som skolen stod færdig gik Tvis Kommune sammen med de to idrætsforeninger om gennem frivilligt arbejde at etablere et stort fælles stadion med klublokaler og omklædningsrum til $150.000 \mathrm{kr}$. ved siden af skolen. Da det stod færdigt i 1968 flyttede Tvis KFUM \& K’s Idræt sine idrætsaktiviteter hertil. Fællesaftener fandt stadig sted i samarbejde med KFUM \& K i missionshuset, mens amatørteater og fester blev placeret i de mere rummelige lokaler i sognegården eller FDF-hytten Knuden. Ved festerne var der taler og sange med et kristent indhold efterfulgt af sanglege og endda fra 1968 - efter en del debat i bestyrelsen - folkedans, men der blev ikke serveret alkohol. Flytningen af håndbolden fra krat til stadion betød, at den fælles andagt for alle hold forsvandt og at holdfællesskabet kom til at dominere over klubfællesskabet, da alle holdene ikke trænede de samme dage. Samtidig mødte KFUM-medlemmerne nu naturligt TIUF-medlemmerne på stadion, og til 
ærgrelse for den ældre generation begyndte de unge spillere efterhånden at tage 1970'ernes bykultur til sig i form af alkohol, urent sprog, kortspil og moderne pardans. I bestyrelsen holdt man imidlertid den ideologiske fane højt ved indtil 1977 at afslå tilbud om at deltage i en sommerfest med idrætsforeningen og borgerforeningen, da der blev serveret alkohol (Bak 2014, s. 28-81).

\section{HALLEN}

Tiden på stadion fra 1968-1977 blev på mange måder en mellemstation. I disse år blev den udendørs sommerhåndbold på landsplan nemlig gradvist distanceret af vinterhåndbold, der nu blev dyrket i de hundredevis af idrætshaller, der skød op i landsbyerne. Tvis KFUM \& K's Idræt havde siden 1959 lejet sig ind i haller i nabobyerne om vinteren, men i 1977 gik man sammen med Tvis Idræts- og Ungdomsforening og Tvis Borgerforening om at samle ind til en hal. Husstandsindsamlingen gav på én aften 120.000 kr., der blev suppleret med 1 mio. kr. fra Holstebro Kommune. Hallen blev taget i brug i november 1977 - omklædningsrum og kantine dog først i april 1978 - og ved den officielle indvielse 11.-12. november 1978 var der dans og alkohol til festen om lørdagen og venskabskampe mellem sognets to klubber om søndagen.

Tvis Hallen og samarbejdet mellem de to klubber blev startskuddet til en sportslig optur for håndbolden. 29. august 1979 indgik de to bestyrelser en skelsættende aftale om at dele aktiviteterne mellem sig, så man ikke konkurrerede om de samme spillere. KFUM fik nu eneret på håndbold og volleyball, mens idrætsforeningen tog sig af resten. Det betød, at talenterne nu kunne samles på fælles hold, og da centralskolens idrætsvenlige inspektør Helge Jensen på fremsynet vis havde ansat en række unge håndboldspillere og -trænere som lærere, blev der i 1980’erne og 1990'erne skabt et stærkt håndboldmiljø i KFUM-regi. Hovedfokus var nu på vinterturneringen under JHF, hvor kampene blev spillet om søndagen, også i kirketiden, men holdene deltog samtidig i KFUM-turneringen om lørdagen, mens sommerhåndbolden på stadion mere eller mindre forsvandt i løbet af 1980'erne. Mens antallet af medlemmer lå på 50-100 i tiden i krattet og på stadion, så steg det til 180 i 1982 og kulminerede med 440 i 1996. På dette tidspunkt havde klubben 32 hold, heraf hele syv herreseniorhold. Sportsligt var herreholdet klubbens flagskib. Med lærerne Kurt Nielsen og Ulrik Jensen som trænere og Agner Lund som formand rykkede førsteholdet fra serie 3 i 1982 til 1. division i 1993. I takt med at holdet rykkede op gennem rækkerne, steg tilskuerinteressen og talenter kom til fra naboklubberne (Bak 2014; 2016). 


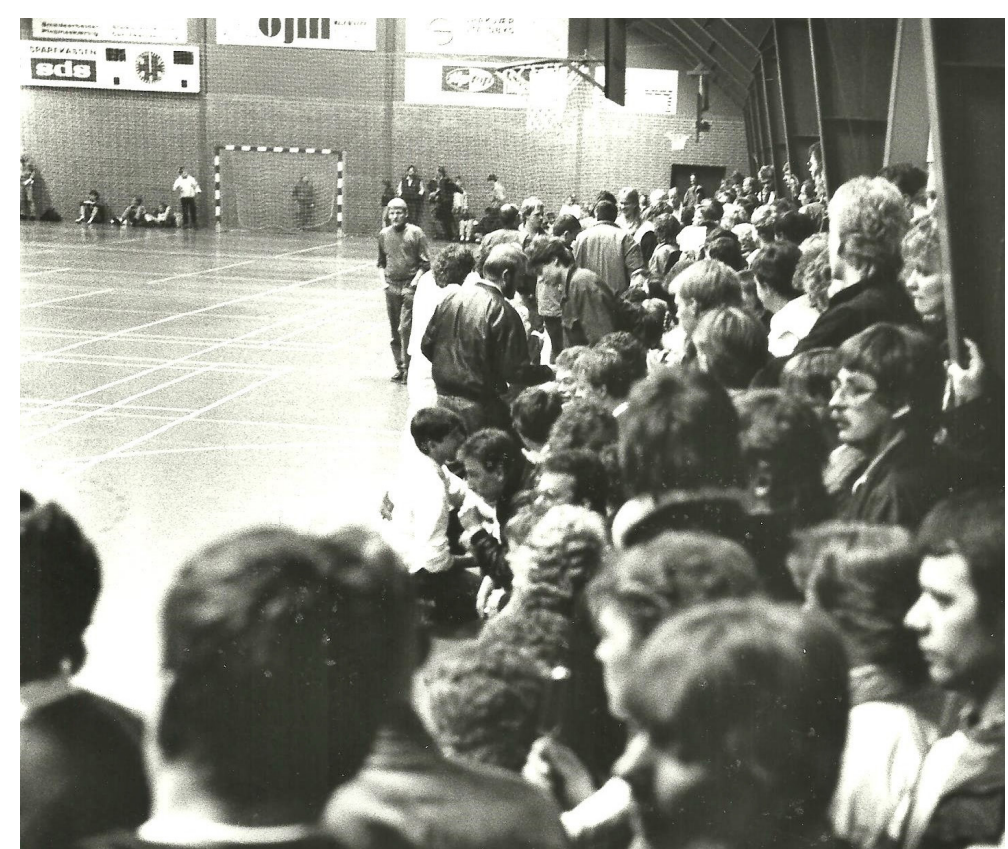

Figur 2: Tvis Hallen i 1980'erne. Tvis KFUM Idræts hjemmebane fra 1978. Kapacitet: 600 tilskuere. Foto: Bent Bak.

I perioden fra 1986 til 1990, hvor holdet spillede i 3. division nord, var der op til 600 tilskuere presset ind i Tvis Hallen til lokalopgørene mod Hvam HK, Fousing IF, Holstebro KFUM og Holstebro HK. Hallen var en relativt lille hal uden tribuner. For at få plads til de mange tilskuere blev der sat bænke op tæt på sidelinjen på begge langsider. Her sad hovedsageligt ungdomsspillerne, ofte med fødderne et stykke inde på banen. Bag bænkene stod så én eller to rækker tilskuere og bag dem endnu en række oven på lukkede boldkasser langs væggen. De trofaste støtter havde deres faste ståpladser, hvor de kom og så håndbold søndag eftermiddag, hvor førsteholdet som regel spillede. Bent Bak beskriver oplevelsen i Tvis Hallen i 1980’erne således:

"Alle som har oplevet de spændende og succesrige kampe i den tætpakkede Tvis Hal glemmer det aldrig. Tilskuerne og spillerne var så tætte på hinanden, at hvert et ord på banen kunne høres og sveden bogstavelig talt sprøjtede ud på tilskuerne. Der var tæt i hallen og fugtigheden høj. Nogle tilskuere havde deres faste sidde-eller ståpladser søndag efter søndag. Det var med at komme i god tid. Når hallen forst var fyldt, var det svært at forflytte sig rundt." (Bak 2016, s. 22)

Konsekvensen af den sportslige succes var en afideologisering, hvor klubbens kristne værdigrundlag blev mindre tydeligt. Der kom efterhånden mange spillere 
og ledere til, der ikke havde tilknytning til Indre Mission, og samtidig lod de unge fra missionske hjem sig påvirke af de nye holdkammeraters mere verdslige livsstil. Som i mange andre sportsligt succesfulde KFUM-håndboldklubber som fx Fredericia KFUM gik udviklingen således fra et kristent til et sportsligt fællesskab. I Tvis' landbokultur skete det dog tyve år senere end i Fredericias bymiljø, men begge steder skete det parallelt med den sportslige succes (Christensen 1999; Jepsen 1993).

Fra 1981 tillod Tvis KFUM Idræt servering af alkohol til fester, og med nedlæggelsen af det civile Tvis KFUM \& K i 1983 holdt klubben op med at afholde fællesmøder og generalforsamlinger i missionshuset, og samtidig mistede det missionske bagland to pladser i bestyrelsen (Bak 2016).

Et resultat af klubbens vækst og sekularisering blev et nyt idégrundlag vedtaget i 1991. Det var blevet til gennem en medlemsdebat og udmærkede sig ved at lægge vægt på demokratisk dannelse frem for kristen forkyndelse. Foreningen ønskede således at præge ungdommen til at tage ansvar for fællesskabet "gennem en aktiv stillingtagen og medleven i klubbens daglige liv", mens det nærmeste man kom på et kristent islæt var ambitionen om "at skabe et godt klima for kammeratskab og samvær i forbindelse med udøvelse af håndboldspil i klubben" (Tvis KFUM Idræt 1991, s. 3). Ifølge vedtægterne var foreningens formål imidlertid stadig "at skabe gode og sunde rammer omkring idrætten, og at forkynde det kristne evangelium for foreningens medlemmer." I 1992 tolkede formand Agner Lund det kristelige 'K' i foreningens navn på denne måde:

"K'et har dog ikke mistet sin betydning, selvom vi ikke forkynder det kristne evangelium i forbindelse med idrætsudøvelse i klubben, så har vi dog på ledelsesplan nogle diskussioner omkring, at vi skal forsøge at leve op til noget, som for mig at se er væsentligt med det kristne budskab, at man behandler sine medmennesker ordentligt, og at man også vil være noget for sine medmennesker udover i forbindelse med det rent idrætslige." (Laursen 1992, s. 24)

Én af de måder, hvorpå foreningen arbejdede med den menneskelige dannelse af de mange unge spillere og trænere, var ved at sende dem på KFUM's Idrætsforbunds sommerkursus på Hellebjerg Idrætsungdomsskole, hvor de ud over håndbold lærte om foreningsliv og kristendom. Blandt foreningens medlemmer var der i 1990'erne ikke kritik af bestyrelsens nytolkning af det kristne aspekt. De interne værdidebatter drejede sig nu snarere om forholdet mellem bredde og elite. Gennem et systematisk ungdomsarbejde og etableringen af et økonomisk fundament i form af lokale virksomheder som Gråkjær Staldbyg og Tvis Køkkener stod man i 1990'erne med både senior- og ungdomshold blandt Jyllands bedste. Det betød, at der var en fare for, at elitens sportslige resultater kom til at skubbe breddens fokus på kammeratskab og samvær i baggrunden. Derfor måtte bestyrelsen forsøge at 
balancere mellem de to sider og interesser i foreningen ved "at fordele ressourcerne på en rimelig måde, således", "at klubbens fundament (bredden) aldrig kommer i fare" og "at eliten til stadighed kan markere sig resultatmæssigt" (Tvis KFUM Idræt 1991, s. 3; Laursen 1992, s. 22-29).

\section{CENTRET}

Da Tvis KFUM's herrer i 1990 rykkede op i 2. division vest og dermed blev Nordvestjyllands førende hold, fik andre end de 1.800 indbyggere i Tvis Sogn interesse for klubben. Man kunne nu trække tilskuere fra hele Holstebro-området ved at flytte kampene til Idrætscenter Vest, der ligger på den anden side af Holstebro, 13 km nordøst for Tvis. Første turneringskamp på Vest var mod Skjern GF 10. december 1990, hvor 1.500 tilskuere så Tvis KFUM vinde med 23-15. Disse to klubber blev i 1990'erne dominerende i Vestjylland og har siden været lokalrivaler på den store scene i landets to bedste rækker. I forbindelse med kvalifikationsspillet til 1. division i foråret 1991 satte Tvis KFUM sæsonens tilskuerrekord i Danmarksturneringen med 1.802 tilskuere mod Tarup Pårup. Fra sæsonen 1991/92 blev Idrætscenter Vest førsteholdets faste hjemmebane, og planer om at udvide Tvis Hallen blev skrinlagt (Hjermitslev 2000; Bak 2016). Sportsligt blev 1990'erne en kamp for at etablere sig i landets bedste række. Her optrådte Tvis KFUM i 1993-94, 1996-98 og igen i 1999-2000, hvor klubben nåede DM-semifinalerne. Herefter dannedes der et holdfællesskab med Holstebro Håndbold 90 under navnet Team Tvis Holstebro, der siden har spillet i herrehåndboldligaen (Bak 2016).

1990'erne var kendetegnet ved en professionalisering og kommercialisering af dansk klubhåndbold. Parallelt med landholdenes succes - først damernes og derefter herrernes - steg tilskuer-, TV- og sponsorinteressen. Mange spillere og ledere blev nu halv- eller heltidsprofessionelle, og der begyndte at komme udenlandske spillere til (Storm 2008). Professionaliseringen var allerede så småt begyndt i Tvis KFUM i 1988 med etableringen af et økonomiudvalg og en bilordning for spillerne og fortsatte i 1990 med, at spillerne blev købt fri til træning og i 1998 med, at Agner Lund blev ansat som forretningsfører på kvart tid. På denne tid blev der også etableret en erhvervsklub og en fanklub, og de første udenlandske spillere kom til klubben. De var dog ikke professionelle, men arbejdede på lokale virksomheder ved siden af håndbolden. I 1999 blev holdets anfører John Mikkelsen ansat som forretningsfører, og der blev oprettet et sekretariat i en nedlagt kartoffelcentral i Tvis ejet af den lokale virksomhed Marmorhuset (nu Actona Company). I spidsen for denne professionalisering stod blandt andre direktør og storsponsor John Gråkjær, der som formand fra 1997-2000 også indledte en dialog med én af landets største håndboldklubber Holstebro Håndbold 90 (en sammenslutning mellem Holstebro KFUM og Holstebro HK fra 1990) om at skabe et holdfællesskab, 
der med et større sponsor-, tilskuer- og spillergrundlag kunne bringe Holstebro Kommune helt til tops i dansk og europæisk håndbold. Tvis KFUM’s omsætning var steget fra $39.000 \mathrm{kr}$. i 1980, over $800.000 \mathrm{kr}$. i 1990 og 1,5 mio. kr. i 1997 til 2,6 mio. kr. i 2000, men der var brug for flere indtægter for at kunne hamle op med de etablerede ligaklubber, der nu havde omsætninger på omkring 5 mio. kr. og spillere på halvtids- og fuldtidskontrakter (Bak 2016; Storm \& Almlund 2006).

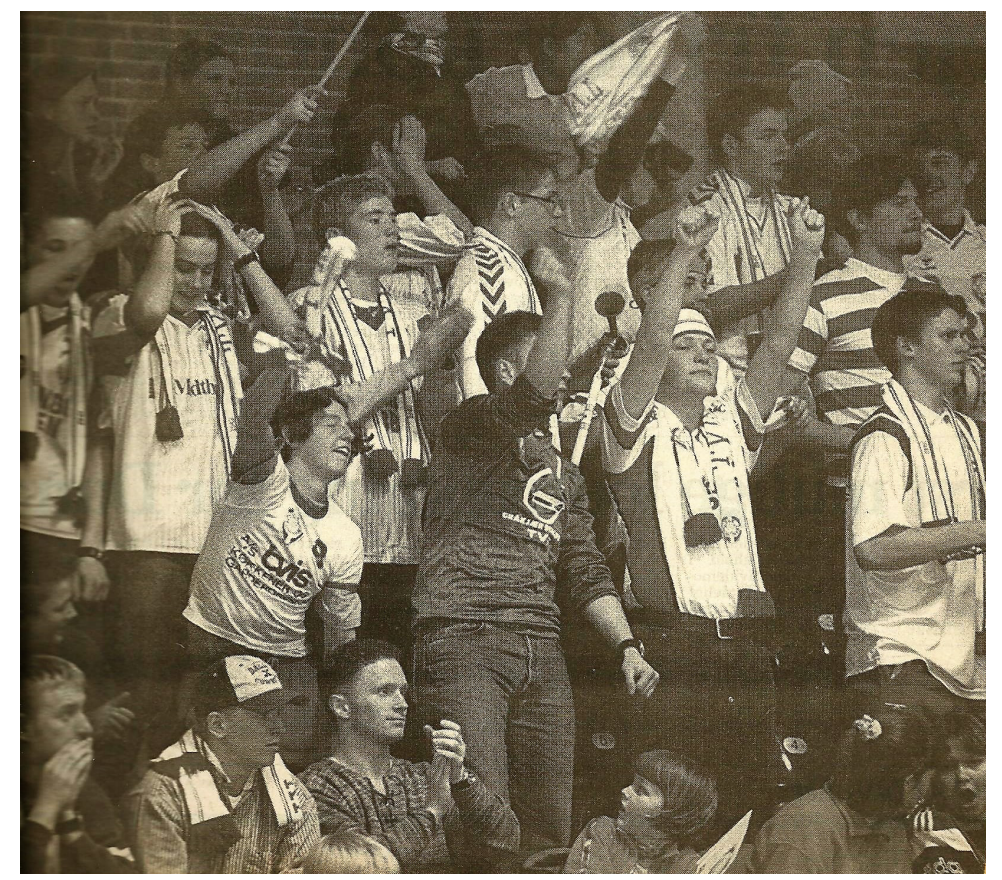

Figur 3: Idrætscenter Vest i Holstebro. Tvis KFUM's førsteholds hjemmebane 1991-2000 og Team Tvis Holstebros hjemmebane 2000-2010. Kapacitet: 2.100 tilskuere. I 1996 stiftedes Tvis KFUM Support "De rødhvide Bønder". Navnet refererer til klubbens farver og dens historiske rødder i landbokulturen. På billedet fejrer fanklubben Tvis KFUM's sejr på 22-20 over Holte IF 16. februar 1997 foran 800 tilskuere. Den var blandt landets første håndboldfanklubber og samlede op mod 100 unge til slagsange i Blok $\mathrm{F}$ til hjemmekampene. Efter holdfællesskabet i Team Tvis Holstebro fortsatte den i mindre målestok under navnet Team Tvis Holstebros Fanklub Flammen (Hjermitslev 2016). Fanklubben kan findes på hjemmesiderne bondehold.dk og flammen.dk. Foto: Jesper Voldgaard, Dagbladet Holstebro.

\section{ARENAEN}

I perioden fra 1993 til 2006, hvor kommercialiseringen og professionaliseringen af dansk klubhåndbold fandt sted, skete der store ændringer i det idrætslige landskab. Håndboldklubberne gik fra at være lokale foreninger drevet af frivillige til at blive en del af oplevelsesøkonomien med professionelle selskaber, nye håndboldarenaer og fuldtidsansatte medarbejdere, og langt de fleste klubber fusionerede eller indgik i samarbejde med kommercielle fodboldklubber for at kunne klare sig i den økonomiske og sportslige konkurrence. På trods af en stigende omsætning 
i herre- og dameligaklubberne fra gennemsnitligt 2 mio. i 1998 til 12 mio. i 2006, så kunne resultaterne på bundlinjen ikke følge med. Håndbold - ligesom sport generelt - var således en notorisk dårlig forretning, hvor ønsket om sportslige resultater resulterede i økonomiske vanskeligheder, og de fleste klubber kæmpede med underskud, og enkelte selskaber gik konkurs (Storm \& Almlund 2006; Storm 2008; Idan 2018).

Tvis KFUM er et typisk eksempel på klubhåndboldens professionalisering i denne periode. Den lokalt forankrede forening blev fusioneret på eliteniveau i $2000 \mathrm{og}$ blev i 2003 omdannet til et aktieselskab for i 2009 at blive et holdingselskab under navnet Holstebro Sport + Event med Team Tvis Holstebro Herrer og Team Tvis Holstebro Damer som datterselskaber. I 2011 blev den nye hjemmebane Gråkjær Arena indviet i det nordlige Holstebro, 9 km fra Tvis. Omsætningen steg fra 6,5 mio. kr. i det første år som Team Tvis Holstebro til 15,8 mio. kr. i sæsonen 2008/2009, hvor herreholdet vandt både pokalturnering og bronze for første gang. Siden 2009 har både dame- og herreholdet været i ligaen og vundet adskillige nationale og europæiske medaljer, men samtidig har selskabet de fleste år haft underskud på driften trods en omsætning på op til 25 mio. kr. (heraf ca. 2/3 til herreholdet) og har derfor i flere omgange måttet nedprioritere dameholdet for at holde skindet på næsen. Det har også været på tale at slå herreholdet sammen med Viborg eller Lemvig og dameholdet med Ringkøbing eller Struer for at skabe et endnu større sponsorgrundlag (Team Tvis Holstebro 2014; Bak 2016; Idan 2018). ${ }^{2}$

Konsekvensen af professionaliseringen blev en delokalisering. Førsteholdene og de bedste ungdomshold flyttede fra Tvis til Holstebro, og stadig flere spillere, ledere og trænere kom til udefra på fuldtidskontrakter. Afstanden mellem tilhængere og spillere, og mellem bredde og elite, blev dermed større, og spørgsmålet om fællesskab og tilknytning blev af stor betydning. Dette blev særligt tydeligt i forbindelse med dannelsen af holdfællesskabet Team Tvis Holstebro i 2000 og debatten om en navneændring i 2013.

Holdfællesskabet om Team Tvis Holstebro blev vedtaget med stor tilslutning ved ekstraordinære generalforsamlinger i begge moderklubber 10. februar 2000 (90 mod 13 i Tvis KFUM og 116 mod 10 i HH9o). Den mest prominente modstander af den fælles overbygning var Tvis KFUM's tidligere formand fra 1993-97 Iver Andersen, der udtalte: "Jeg ser Tvis KFUM som et stykke af mig selv, og hvis man

2 Professionaliseringen i Danmark foregik godt 10 år efter den havde fundet sted i Tyskland. Historien om SG Flensburg-Handewitt har da også klare paralleller til historien om Team Tvis Holstebro. I 1990 blev TSB Flensburg fusioneret med landsbyklubben Weiche-Handewitt (et holdfællesskab mellem ETSV Weiche og Handewitter SV), der havde succes i den lille og intense Wikinghalle i Handewitt, men kæmpede for at skaffe sponsorer til at etablere sig i Bundesligaen. Bakket op af det regionale erhvervsliv blev løsningen en fusion mellem Handewitt og Flensburg med hjemmebane i Flensburg. I 1992 rykkede fusionsklubben op i Bundesligaen, og fra 1997 og frem høstede den mange nationale og internationale medaljer (Ryom 2017). 
vælger at slå de to klubber sammen, tager jeg konsekvensen og siger farvel og tak" (Bak 2016). Langt de fleste frivillige blev dog i de to klubber, og der blev nu indledt et samarbejde om herrerne i den bedste række og damerne i den næstbedste række. Ny formand for Team Tvis Holstebro blev John Gråkjær fra Tvis, der i repræsentantskabet og udvalgene blev suppleret med erhvervsfolk og repræsentanter fra moderklubberne. Samtidig ansatte man nu tre medarbejdere i administrationen, der fortsat holdt til i Tvis, hvor herrerne også trænede flere gange om ugen. Samarbejdet blev dog langt fra problemfrit. Tvis KFUM kom med et herreligahold, de fleste sponsorer samt en erhvervsklub og en fanklub, mens HH9o bragte et 1. divisions damehold, en stor ungdomsafdeling og et påskestævne, men også økonomiske vanskeligheder, med ind i samarbejdet. Det skabte en vis mistillid, og da der samtidig var uenighed om prioriteringen af herre- og dameholdet og om ungdomsholdene, var samarbejdet tæt på at kuldsejle i 2002, hvor samarbejdsaftalen skulle genforhandles oven på et underskud på 900.000 kr. i det første regnskabsår. Samtidig trak én af hovedarkitekterne bag samarbejdet John Gråkjær sig som formand. Med den nye formand Orla Dahl Jepsen fra Actona Company i Tvis for bordenden lykkedes det dog i andet forsøg i 2002 at forhandle en holdbar samarbejdsaftale på plads med moderklubberne, der fastslog, at klubbens førsteprioritet var herreholdet trods dameholdets oprykning til den på dette tidspunkt mere profilerede dameliga. Samtidig blev Team Tvis Holstebro omdannet til et aktieselskab, der fik større råderum i forhold til moderklubberne (Team Tvis Holstebro 2014; Bak 2016).

I maj 2013 opstod der igen gnidninger i samarbejdet, da John Gråkjær, der var tilbage som formand, men nu bosiddende i Holstebro, meldte ud, at Team Tvis Holstebro efter ønske fra potentielle sponsorer og Holstebro Kommunes borgme-

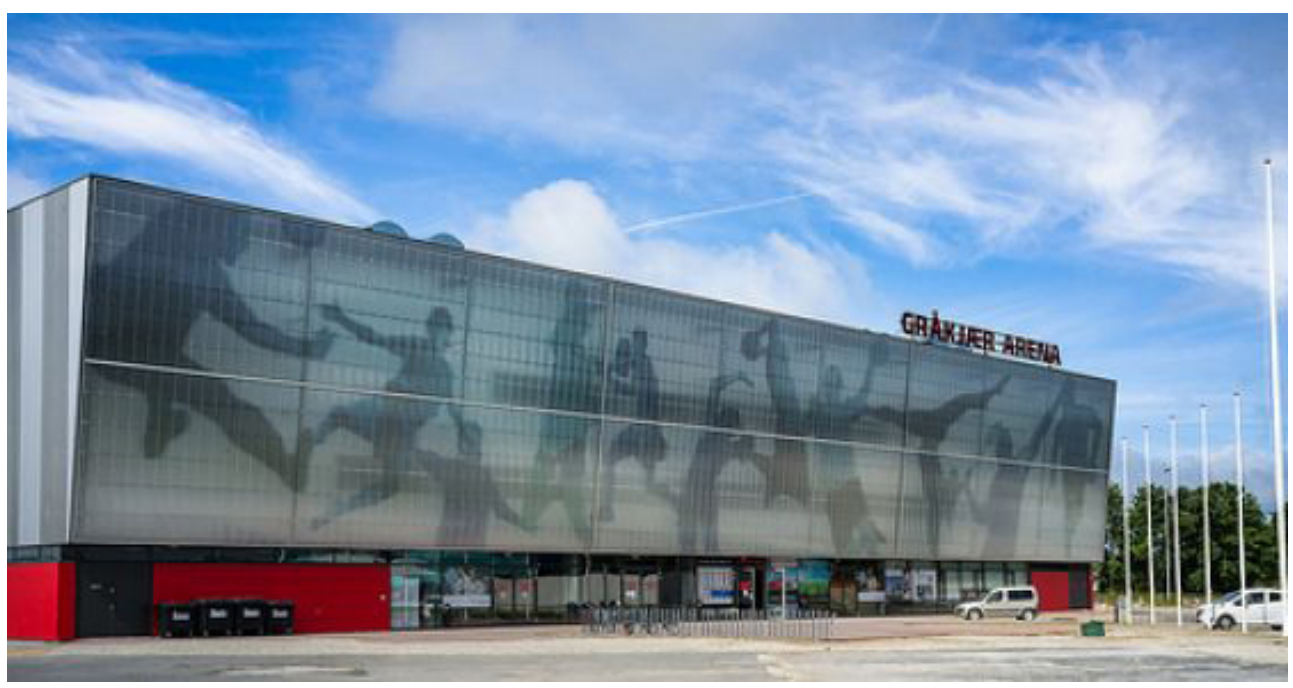

Figur 4. Gråkjær Arena. Team Tvis Holstebros hjemmebane fra 2011. Kapacitet: 3.250 tilskuere. Arenaen i Holstebro er blandt landets bedst konstruerede håndboldarenaer med en intim atmosfærre, der understøttes af klubbens to nye fanklubber TTH Support (2009) og TTH Dragons (2016). Alle TTH's faciliteter er samlet i arenaen. Foto: hfoto. 
ster H.C. Østerby, der havde en fortid i Holstebro Håndbold 9o, skulle skifte navn, så centerbyen Holstebro kunne blive fremhævet på bekostning af landsbyen Tvis. Selv om Tvis KFUM's formand Erling Kristensen modvilligt accepterede ideen, så mobiliserede græsrødder fra Tvis med tilknytning til den gamle fanklub Flammen en omfattende kampagne i pressen og de sociale medier, der resulterede $\mathrm{i}$, at over 1.ooo personer tilmeldte sig facebooksiden "Bevar Team Tvis Holstebro" under sloganet "Husk rødderne!". Initiativtager Thomas Hjermitslev anklagede Team Tvis Holstebros bestyrelse for udemokratiske metoder og manglende historisk bevidsthed:

"Folk oplever, at bestyrelsen har glemt, at de driver en sportsklub og ikke en pølsebod. Jeg mener, at bestyrelsen må respektere klubbens historie og det engagement, som de mange tilskuere, fans og frivillige har i klubben. Navnet Team Tvis Holstebro er et kompromis, som moderklubberne indgik ved fusionen i 200o. Det kan bestyrelsen ikke bare ignorere." (Flammen 2013)

At Tvis indgik i navnet var afgørende for mange, da det trak tråde tilbage til stedet, hvor succesen begyndte i 1980'erne. At fjerne Tvis fra navnet ville være at fjerne tilknytningen til landsbyen, der allerede havde oplevet, at sekretariatet og førsteholdets træning var forsvundet fra landsbyen. Den omfattende kritik af bestyrelsens idé betød, at navneændringen blev sat i bero. I juni 2016 gjorde bestyrelsen imidlertid alvor af truslen og ændrede uden forudgående debat navnet til TTH Holstebro; et navn, Flammen i 2013 havde foreslået som et kompromis. Bestyrelsen havde ifølge formand Jørgen Hansen lyttet til debatten fra 2013:

"Med fastholdelse af TTH $i$ klubbens navn, så vil vi bevare vores rødder og fortsætte vores klubarbejde i tæt samarbejde med de to moderklubber. Vi ved, at det kan gøre ondt på nogen i Tvis-området, men tingene har udviklet sig, og tiden er nu moden til skiftet." (Team Tvis Holstebro 2016)

I Tvis vakte beslutningen ikke samme debat som i 2013. TTH havde gradvist fjernet sig fra landsbyen og derfor var navneændringen en naturlig konsekvens af udviklingen. Mens eliten på senior- og ynglingeniveau flyttede til Holstebro, levede Tvis KFUM's håndboldaktiviteter imidlertid videre i Tvis Hallen, der i mellemtiden var blevet omdannet til Tvis Centret. Klubben havde også fjernet KFUM fra navnet, da man i 2012 besluttede at slå landsbyens to idrætsforeninger sammen, først under navnet Tvis KFUM \& IF og senere det mere mundrette TVIS. Trods betydeligt færre medlemmer end i storhedstiden i slutningen af 1990'erne, udmærkede håndboldafdelingen sig stadig i 2010'erne med et godt ungdomsarbejde, mens bredden på seniorsiden - som i mange andre klubber i disse år - blev kraftigt reduceret. 
Mange af Tvis KFUM’s gamle spillere var nu aktive som ledere, trænere og frivillige i Team Tvis Holstebro, mens der kun var enkelte spillere fra Tvis på førsteholdet. Som betaling for licensen til ligaherreholdet modtog TVIS håndbold årligt et klækkeligt beløb fra TTH til at finansiere ungdomsafdelingens talentarbejde. På denne måde betalte den professionelle topklub af på den historiske gæld til landsbyen, hvor herrehåndbolden begyndte i 1942.

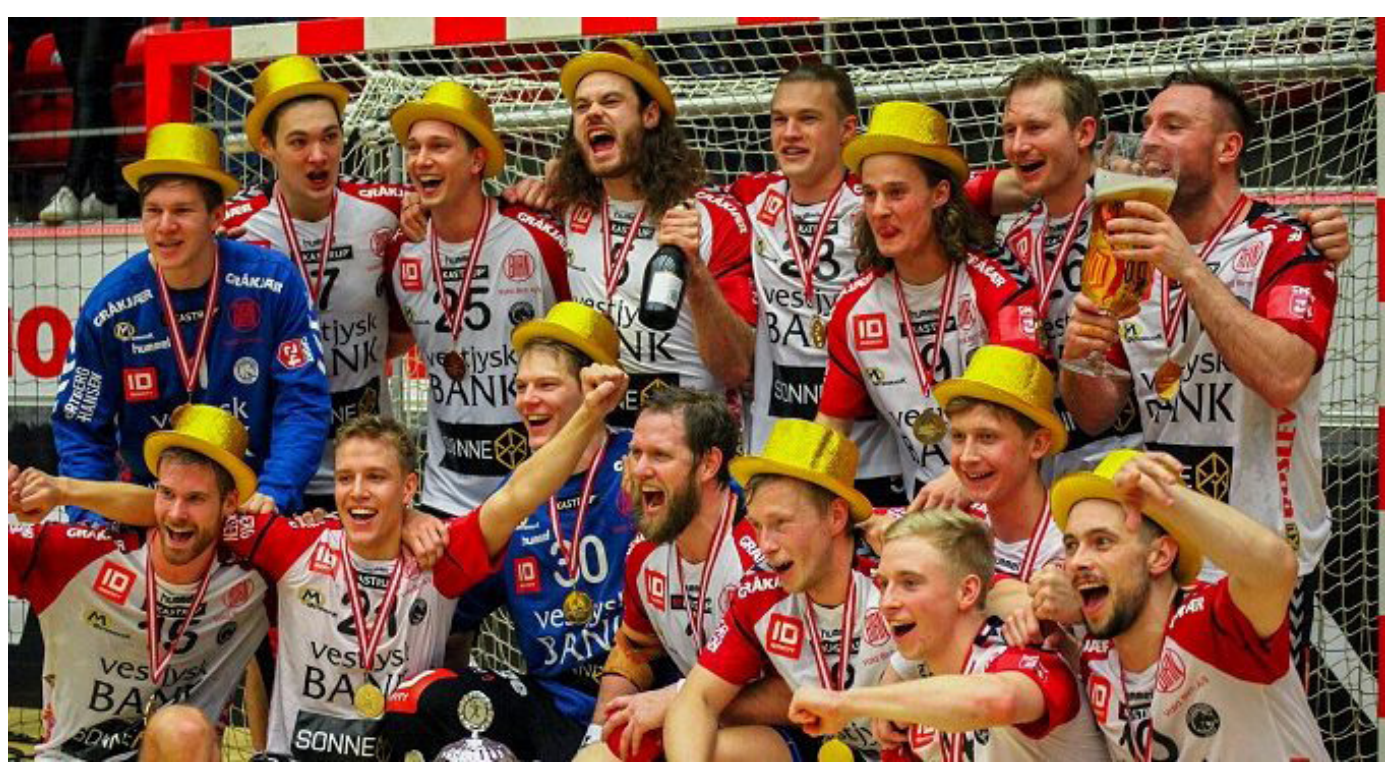

Figur 5: TTH Holstebros pokalvindere 2017/2018. I februar 2018 lagde Gråkjær Arena gulv til hjemmeholdets sejr i pokalturneringens Final Four, hvor TTH besejrede Ribe/Esbjerg EH med 26-25 i semifinalen og GOG med 26-21 i finalen. Dermed sikrede klubben sig sin anden pokaltitel. Første gang det skete, var i Arenaen i Aarhus i december 2008, hvor Team Tvis Holstebro ligeledes vandt finalen over GOG Svendborg TGI. Dengang med 31-25. Foto: MinByHolstebro.dk.

\section{KONKLUSION}

Som denne artikel har vist, så er historien om Tvis KFUM mere end en lokal idrætshistorie. Ud fra det specifikke sted i en landsby i Vestjylland $7 \mathrm{~km}$ sydøst fra Holstebro tegner der sig nemlig et større billede af håndboldens historie i Danmark, som mange andre KFUM- og landsbyklubber sikkert vil kunne nikke genkendende til. Det er historien om udviklingen fra landbokulturens ideologisk prægede udendørshåndbold på marken i tiden omkring Anden Verdenskrig til indendørshåndbold i velfærdssamfundets idrætshaller i 1970'erne og for de mest succesfulde klubbers vedkommende videre til idrætscentre og håndboldarenaer fra 1990’erne og frem. På vejen til toppen måtte de tage afsked med de gamle steder og værdier til fordel for en kommercialisering og professionalisering, der førte elitehåndbolden fra foreningslivet og lokalsamfundet til forretningsverdenen og oplevelsesøkonomien. Det er denne store historie, som den lille historie om Tvis KFUM fortæller. 


\section{REFERENCER}

Bak, B. (2014). Tvis KFUM Idræts historie 1942-1982, Tvis Lokalhistorie. Hentet fra: http://kulturelle-samvirke.tvisby.dk/idraet-i-tvis.html.

Bak, B. (2016). Tvis KFUM Idræts historie 1982-2002. Tvis Lokalhistorie. Hentet fra: http://kulturelle-samvirke.tvisby.dk/idraet-i-tvis.html.

Bak, B (2018). Tvis Forsamlingshus og Sognegård 1909-2017. Tvis Lokalhistorie. Hentet fra: http://kulturelle-samvirke.tvisby.dk/pages/webside.asp?articleGuid=196525.

Carlsen, J. \& Henriksen, S. (2018). Fodboldens historie i Tvis 1923-2012. Tvis Lokalhistorie. Hentet fra: http://kulturelle-samvirke.tvisby.dk/idraet-i-tvis.html.

Christensen, K.V. (1999). Håndbold i kristendommens tegn. Idrætshistorisk Årbog, 15, 4769. Hentet fra: https://tidsskrift.dk/forumforidraet/article/view/31758/29195.

Fibiger, L.B. (2018). Grundtvigianisme og Indre Mission i Tvis sogn, Tvis Lokalhistorie. Hentet fra: http://kulturelle-samvirke.tvisby.dk/kirkelige-forhold.html.

Flammen (2013). TTH-fans siger nej til nyt navn. Pressemeddelelse.

Halgaard, Jacob \& Bak, Bent (2018). Gymnastikhistorien. Tvis Idrætsforening 1909-1975. Tvis Lokalhistorie. Hentet fra: http://kulturelle-samvirke.tvisby.dk/idraet-i-tvis.html.

Hjermitslev, H.H. (2000). Tvis KFUM scrapbøger og kampprogrammer 1986-200o. Privatarkiv.

Hjermitslev, H.H. (2016). 20 år med hele Danmarks bondehold. Hentet fra www.flammen. $\mathrm{dk} /$ metaflammen/20-aar-med-hele-danmarks-bondehold/.

Idan (2018). Diverse analyser og rapporter om håndbold. Hentet fra: www.idan.dk/.

Jepsen, A.L. et al. (1993). KFUMs Idrætsforbund i Danmark 1918-1993. Horsens: KFUMs Idrætsforbund i Danmark.

Korsgaard, O. (1997). Kampen om kroppen - Dansk idræts historie gennem 200 år. 3. udg. København: Gyldendal.

Laursen, D.N. (1992). Den organiserede foreningsidræt i Danmark. Den større skriftlige opgave 1991/92. Holstebro Gymnasium og HF-Kursus.

Nielsen, N.K. (2008). Dansk håndbold - Fra topografi til oplevelsesøkonomi. In R.K. Storm \& U. Almlund (red.), Dansk håndbold - bredde, elite og kommercialiseringens konsekvenser (pp. 44-76). Gerlev: Bavnebakke.

Nielsen, N.K. (2010). Krop, topografi og kulturelle transformationer - Dansk håndbold som case. Slagmark, 57, 93-106.

Ryom, L. (2017). Grænseløs lidenskab. En dansk-tysk håndboldhistorie. Byens Forlag. 
Storm, R.K. red. (2008). Dansk håndbold - bredde, elite og kommercialiseringens konsekvenser. Gerlev: Bavnebakke.

Storm R.K. \& Almlund, U. (2006). Håndboldøkonomi.dk - fra forsamlingshus til forretning. København: Idrættens Analyseinstitut. Hentet fra www.idan.dk/vidensbank/udgivelser/haandboldoekonomidk-fra-forsamlingshus-til-forretning-(rapport)/687598dd-758 c-42fd-b33d-97eoooe474ce.

Team Tvis Holstebro (2014). Scrapbøger 2000-2014. Team Tvis Holstebros Arkiv.

Team Tvis Holstebro (2016). TTH Holstebro tilpasser navnet. Hentet fra www.tthholstebro.dk/nyheder/tth-holstebro-tilpasser-navnet.

Tvis KFUM Idræt (1991). Tvis KFUM’s håndboldafdeling. Privattryk.

HANS HENRIK HJERMITSLEV er ph.d. i videnskabshistorie fra Aarhus Universitet (2010) og lektor ved Pædagoguddannelsen i Aabenraa og Forskningsprogram for Dagtilbud og Skole, UC SYD, hvor han underviser og forsker i pædagogikkens historie og dansk dannelsestænkning. Han har udgivet en række videnskabelige artikler om grundtvigianisme, folkeoplysning og dannelse og har senest bidraget til Thomas Aastrup Rømer, Lene Tanggaard og Svend Brinkmann (red.), Uren pædagogik 3 (Klim 2017) og Merethe Roos og Johan Tønnesson (red.), Sann Opplysning? Naturvitenskap i nordiske offentligheter gjennom fire århundrer (Cappelen Damm 2017). 